\title{
Toxoplasma gondii, Neospora caninum and Leishmania amazonensis antibodies in domestic dogs in the western Brazilian Amazon region
}

\section{Toxoplasma gondii, Neospora caninum e Leishmania amazonensis em cães domésticos da Amazônia Ocidental Brasileira}

\author{
Sérgio de Almeida BASANO ${ }^{1,3}$; Paulo TARSO ${ }^{1}$; Herbert Sousa SOARES ${ }^{2}$; Andrea Pereira COSTA ${ }^{2}$; Arlei \\ MARCILI $^{2,5}$; Marcelo Bahia LABRUNA ${ }^{2}$; Ricardo Augusto DIAS ${ }^{2}$; Luís Marcelo Aranha CAMARGO ${ }^{1,4}$; \\ Solange Maria GENNARI ${ }^{2}$
}

\author{
${ }^{1}$ Faculdade São Lucas, Porto Velho - RO, Brazil \\ ${ }^{2}$ Universidade de São Paulo, Faculdade de Medicina Veterinária e Zootecnia, São Paulo - SP, Brazil \\ ${ }^{3}$ Hospital Cemetron, Porto Velho - RO, Brazil \\ ${ }^{4}$ Instituto de Ciências Biomédicas, Departamento de Parasitologia, Monte Negro - RO, Brazil \\ ${ }^{5}$ Universidade de Santo Amaro, Medicina Veterinária e Bem-Estar Animal, São Paulo - SP, Brazil
}

\begin{abstract}
Blood samples from 99 domestic dogs were collected in the urban area $(n=33)$ and rural area $(n=66)$ of the municipality of Lábrea, state of Amazonas, Brazil. Among the rural samples, 40 were collected in riverine communities and 26 were collected in Indian communities, both along the Purus River. During the sampling, a questionnaire was applied to obtain information relating to sex, age, living in dryland or seasonally flooded areas, access to the streets (for urban dogs) and access to forests. The presence of antibodies against Toxoplasma gondii, Neospora caninum, Leishmania infantum chagasi and Leishmania amazonensis was detected by means of the indirect fluorescent antibody test (IFAT) with cutoffs of 16, 50, 40 and 40, respectively. The association of each qualitative variable, with each parasite and positivity for each of them, were evaluated u s i n g test ( $\mathrm{p} \ll 0.05)$. T. gondii, $N$. caninum and $L$. amazonensis antibodies were found, respectively, in $61.6 \%, 7.1 \%$ and $8.1 \%$ of the animals examined. None of the samples were positive for $L$. infantum chagasi. The variable of living in an urban area $(\mathrm{p}=0.041)$ presented an association with occurrence of $T$. gondii and the positivity for $T$. gondii increased with age of the $\operatorname{dogs}(\mathrm{p}=0.0006)$. The variable of male sex presented an association with $N$. caninum $(\mathrm{p}=0.018)$ and no variable presented any association with $L$. amazonensis. The antibody titers against $T$. gondii ranged from 64 to 32,768; against $N$. caninum from 100 to 800; and against $L$. amazonensis from 40 to 640 . Both $T$. gondii and $L$. amazonensis are important zoonotic agents and are active in this region. The municipality studied, and especially its riverine communities, has geographic, social and ecological peculiarities. This region requires greater attention from the authorities for controlling these agents.
\end{abstract}

Keywords: Toxoplasma gondii. Neospora caninum. Leishmania spp.. Amazon. Dogs.

\section{Resumo}

Amostras de sangue de 99 cães domiciliados foram coletadas no meio urbano $(\mathrm{n}=33)$ e rural $(\mathrm{n}=66)$ do município de Lábrea, estado do Amazonas, Brasil. Dentre as amostras rurais, 40 foram obtidas em comunidades ribeirinhas e 26 em comunidades indígenas, ambas ao longo do rio Purus. Durante a amostragem foi aplicado um questionário com informações sobre sexo, idade, viver em áreas secas ou alagadiças, acesso ou não às ruas (cães urbanos) e acesso à floresta. A presença de anticorpos contra Toxoplasma gondii, Neospora caninum, Leishmania infantum chagasi e Leishmania amazonensis foi detectada pela reação de imunofluorescência indireta (RIFI) com ponto de corte de, respectivamente, 16, 50, 40 e 40. Associação entre as variáveis qualitativas e a positividade para cada um dos parasitos foi avaliada pelo teste do $\chi^{2}(\mathrm{p}<0,05)$. A ocorrência de animais com anticorpos contra T. gondii, N. caninum e $L$. amazonensis foi de, respectivamente, 61,6\%; 7,1\% e $8,1 \%$. Nenhuma amostra foi positiva para $L$. infantum chagasi. A variável viver em área urbana $(\mathrm{p}=0,041)$ apresentou associação com ocorrência de $T$. gondii e o número de cães positivos a $T$. gondii aumentou com a idade $(\mathrm{p}=0,0006)$. A variável sexo (machos) apresentou associação com $N$. caninum $(\mathrm{p}=0,018)$ e nenhuma variável apresentou associação com $L$. amazonensis. Os títulos de anticorpos contra $T$. gondii variaram de 64 a 32.768; contra $N$. caninum de 100 a 800 e contra $L$. amazonensis de 40 a 640 . T. gondii e L. amazonensis são dois agentes de importantes zoonoses e encontram-se ativos na região. $\mathrm{O}$ município estudado, especialmente as comunidades ribeirinhas, possuem peculiaridades geográficas, sociais e ecológicas distintas e necessitam maior atenção das autoridades para o controle desses agentes.

Palavras-chave: Toxoplasma gondii. Neospora caninum. Leishmania spp.. Amazonas. Cães. 
Correspondence to:

Solange Maria Gennari

Universidade de São Paulo, Faculdade de Medicina

Veterinária e Zootecnia

Av. Prof. Orlando Marques de Paiva, 87

CEP 05508-270, São Paulo, SP, Brazil

e-mailsgennari@usp.br

Received: $15 / 09 / 2015$

Approved: 08/09/2016

\section{Introduction}

Toxoplasma gondii is a coccidian parasite for which felids are the definitive host and warm-blood animals are the intermediate ones. It is responsible for one of the most important zoonotic diseases (DUBEY, 2010). Antibodies against T. gondii have been found in canine serum samples worldwide and in Brazil the occurrence rate ranges from 5.2\% to $90 \%$ (reviewed by DUBEY et al., 2012). How dogs become infected with $T$. gondii is unknown, but the higher prevalence in stray and farm dogs than in pets has suggested that consumption of infected prey is an important source of infection (SOUZA et al., 2003).

Neospora caninum is an important cause of abortion among cattle worldwide. Canids, including dogs (Canis lupus familiaris), coyotes (Canis latrans), dingoes (Canis lupus dingo) and gray wolves (Canis lupus) (MCALLISTER et al., 1998; GONDIM et al., 2004; KING et al., 2010; DUBEY et al., 2011) play an important role in the epidemiology of this parasite because they are the definitive host, shedding the environmentally resistant oocysts in their feces. Epidemiological studies have reported the presence of dogs as a risk factor for bovine neosporosis (PARÉ et al., 1998; SAWADA et al., 1998; WOUDA et al., 1999). In Brazil, several studies have reported occurrences of antibodies against N. caninum in dogs living in both rural and urban areas. The values, measured by means of the indirect fluorescent antibody test (IFAT $\geq 50 \quad), \quad \mathrm{r}$ a $\mathrm{n} \mathrm{g} \mathrm{e}$ (reviewed by GENNARI, 2004, and by DUBEY; SCHARES, 2011).
The genus Leishmania comprises about 30 different species that infect mammals. These parasites are transmitted by various blood-sucking invertebrates of the family Psychodidae, which are distributed in tropical and subtropical regions (ASHFORD, 2000; DESJEUX, 2004). They can infect humans and cause different clinical symptoms, among which visceral leishmaniasis is the most severe.

Domestic dogs are considered to be the main reservoir of L. infantum chagasi in urban areas and are the main epidemiological source of the parasites, causing visceral leishmaniasis among humans (LAINSON, 2010). Moreover, dogs can be infected by L. amazonensis, which is one of the cutaneous leishmaniasis causal agents (TOLEZANO et al., 2007; HOFFMANN et al., 2012). In Brazil, cutaneous leishmaniasis is a disease of great public health importance, with clinical features ranging from an unapparent form to cases of mucosal and cartilage injury (BRASIL, 2010; GRAMICCIA; GRADONI, 2005).

Studies conducted in Italy (CRINGOLI et al., 2002) and in Brazil (GENNARI et al., 2006) found an association between occurrences of antibodies against L. infantum chagasi and seropositivity for $N$. caninum. No association was observed between $L$. infantum chagasi and T. gondii (GENNARI et al., 2006). These authors reported that immunosuppression due to Leishmania infection was the most likely cause of $N$. caninum infection. However, no studies relating to $L$. amazonensis and positivity for T. gondii or N. caninum are available.

Although several surveillance studies relating to $T$. gondii, N. caninum and Leishmania spp., have been conducted among dogs in Brazil, no study has been undertaken in the state of Amazonas or, particularly, among riverine communities of the Amazon basin, f r o which 3 haye \%geographical, ${ }_{5}$ søcial and ecological peculiarities. Therefore, the present study aimed to determine the occurrence of T. gondii, N. caninum, $L$. infantum chagasi and L. amazonensis antibodies in 
domestic dogs living in communities along the Purus River and in the urban area of the municipality of Lábrea, Amazonas, Brazil.

\section{Material and Methods}

\section{Study area}

Blood samples from domestic dogs were collected in the urban and rural areas of Lábrea, a municipality located in the southern part of the state of Amazonas, Brazil. The climate of that region is humid equatorial (annual precipitation $>2,000 \mathrm{~mm}$ ), with a mean temperature above $25^{\circ} \mathrm{C}$ throughout the year (SILVA et al., 2008). The municipality has a typical Amazon rainforest landscape, with some land permanently flooded (igapós), some land submerged only during rainy seasons (várzeas) and other areas of land that are never submerged (low plains). The municipality encompasses an area of $68,229 \mathrm{~km}^{2}$, with a population of 41,600 inhabitants living mostly in the urban area. Its rural population mostly comprises riverine families (living on the banks of the Purus River). Indian villages also exist in the rural area of the municipality.

\section{Dog sampling}

A total of 99 dogs were sampled, of which 33 were in the urban area and 66 in the rural area of Lábrea, as previously described (SOARES et al., 2014). Among the rural dogs, 40 were owned by people living in riverine communities and 26 were owned by Indians (Table 1). The 33 urban dogs were randomly selected according to their availability in homes during visits. The 66 rural dogs encompassed all the canine populations that were present in each of the six riverine communities and two Indian villages during the visits. During the sampling, a questionnaire was applied to the owners and information on the animals was obtained in relation to: sex, age, rearing mode (restrained or freeroaming), living in dryland or seasonally flooded areas and access to forests.

Table 1 - Geographic localities, number of dogs examined and number of dogs seropositive for T. gondii, N. caninum and L. amazonensis. Lábrea, state of Amazonas - Brazil - 2013

\begin{tabular}{|c|c|c|c|c|c|c|c|c|}
\hline \multirow{2}{*}{ Locality } & \multicolumn{2}{|c|}{ Coordinates } & \multirow{2}{*}{ Living area } & \multirow{2}{*}{$\begin{array}{c}\text { Main } \\
\text { landscape }\end{array}$} & \multirow{2}{*}{$\begin{array}{c}\text { No. of } \\
\text { sampled dogs }\end{array}$} & \multirow{2}{*}{$\begin{array}{c}\text { T. gondii } \\
\text { Positive (\%) }\end{array}$} & \multirow{2}{*}{\begin{tabular}{|l} 
N. caninum \\
Positive (\%)
\end{tabular}} & \multirow{2}{*}{$\begin{array}{l}\text { L. amazonensis } \\
\text { Positive (\%) }\end{array}$} \\
\hline & South & West & & & & & & \\
\hline $\begin{array}{l}\text { Urban area } \\
\text { Rural areas* }\end{array}$ & $07^{\circ} 15^{\prime} 55^{\prime \prime}$ & $64^{\circ} 48^{\prime} 08^{\prime \prime}$ & Urban & Low plain & 33 & $25(75.7)$ & $3(9.1)$ & $4(12.1)$ \\
\hline Carmelitas & $07^{\circ} 16^{\prime} 51^{\prime \prime}$ & $64^{\circ} 50^{\prime} 10^{\prime \prime}$ & Riverine & Várzea & 3 & $3(100.0)$ & $1(33.3)$ & 0 \\
\hline Boca do Ituchi & $07^{\circ} 18^{\prime} 36^{\prime \prime}$ & $64^{\circ} 50^{\prime} 51^{\prime \prime}$ & Riverine & Várzea & 6 & $4(66.6)$ & 0 & 0 \\
\hline Maciari & $07^{\circ} 16^{\prime} 57^{\prime \prime}$ & $64^{\circ} 51^{\prime} 05^{\prime \prime}$ & Riverine & Várzea & 5 & $2(40.0)$ & 0 & 0 \\
\hline Samaúma & $07^{\circ} 18^{\prime} 50^{\prime \prime}$ & $65^{\circ} 08^{\prime} 39^{\prime \prime}$ & Riverine & Várzea & 6 & $4(66.6)$ & 1 (16.7) & 1 (16.7) \\
\hline Santa Rosa & $07^{\circ} 20^{\prime} 28^{\prime \prime}$ & $64^{\circ} 59^{\prime} 50^{\prime \prime}$ & Riverine & Várzea & 12 & $4(33.3)$ & 0 & $1(8.3)$ \\
\hline Bacural & $07^{\circ} 15^{\prime} 02^{\prime \prime}$ & $64^{\circ} 53^{\prime} 03^{\prime \prime}$ & Riverine & Igapó & 8 & $5(62.5)$ & $1(12.5)$ & 0 \\
\hline Jarauara & $07^{\circ} 16^{\prime} 42^{\prime \prime}$ & $65^{\circ} 10^{\prime} 31^{\prime \prime}$ & $\begin{array}{l}\text { Indian } \\
\text { village }\end{array}$ & Low plain & 15 & $10(66,6)$ & 0 & $1(6.7)$ \\
\hline Araça & $07^{\circ} 18^{\prime} 54^{\prime \prime}$ & $64^{\circ} 55^{\prime} 56^{\prime \prime}$ & $\begin{array}{l}\text { Indian } \\
\text { Village }\end{array}$ & Low plain & 11 & $4(36,3)$ & $1(9.1)$ & $1(9.1)$ \\
\hline Total & & & & & 99 & $61(61.6)$ & $7(7.1)$ & $8(8.1)$ \\
\hline
\end{tabular}

*Banks of Purus River

Blood was collected from each dog by means of venipuncture. The serum was separated by means of centrifugation, identified and kept frozen until tested using serological methods.

The procedures of this study had previously been approved by the Animal Ethics Committee of the
Faculty of Veterinary Medicine, University of São Paulo (protocol no. 1667/2009). 


\section{Serological analyses}

An indirect fluorescent antibody test (IFAT) was used to detect $T$. gondii antibodies, with a cutoff value of 1:16 (SILVA et al., 1997). Tachyzoites of the RH strain of $T$. gondii were used as an antigen, as described by Camargo (1974). To detect N. caninum antibodies, IFAT with culture-derived tachyzoites of the NC-1 isolate (DUBEY et al., 1988) was used with a cutoff value of 1:50.

To detect $L$. infantum chagasi and L. amazonensis antibodies, IFAT was performed using a cutoff of 1:40 (BRASIL, 2010). Promastigote forms of $L$. infantum chagasi and L. amazonensis were used as the antigen, as described by Ferrer et al. (1995).

Serum reacting at the cutoff dilution of each of the four antigens was retested at twofold serial dilutions until the last positive dilution. A rabbit anti-canine IgG conjugate labeled with fluorescein (SigmaAldrich, Bellefonte, PA, USA, catalog n-A6792) was used in all the tests, and appropriate positive and negative control serum samples were added to each slide.

\section{Statistical analyses}

The association of each qualitative variable with seropositivity (for T. gondii, N. caninum and $L$. amazonensis) wa s e v a 1 u a $\mathrm{t}$ e dtest.b y The median age (qualitative variable) was compared between seropositive and seronegative animals using the Mann-Whitney test. The significance level in both tests was $5 \%$ and the SPSS 17 software was used to perform the analysis.

\section{Results}

Table 1 presents the geographical localities of the animals and occurrences of antibodies against $T$. gondii, N. caninum and L. amazonensis.
Toxoplasma gondii, N. caninum and L. amazonensis antibodies were found, respectively, in 61 (61.6\%), 7 (7.1\%) and $8(8.1 \%)$ of the 99 dogs examined. None of the samples were positive for L. infantum chagasi.

The category of qualitative variable associated with seropositivity for $T$. gondii was the urban area ( $\mathrm{p}$ $=0.041)$. Since all the rural dogs had contact with forest areas, the association observed between $T$. gondii seropositivity and being kept away from forests $(\mathrm{p}=0.041$ ) was the same association as between seropositivity and living in the urban area. The qualitative variable associated with seropositivity for $N$. caninum was sex (male) ( $\mathrm{p}=0.018$ ), while for L. amazonensis, none of the variables analyzed presented any association with the infection.

Twelve (36.36\%) of the 33 young dogs (from 0 to 1 year old) and $49(74.24 \%)$ of the 66 adult dogs (>1 year of age) were found to be positive for $T$. gondii. The median age was greater among dogs that were seropositive for $T$. gondii $(\mathrm{p}=0.0006)$. Two young dogs (6.0\%) and five adult dogs (7.5\%) were found to be positive for N. caninum, and this difference was not significant $(\mathrm{p}>0.05)$. Two young dogs $(6.1 \%)$ and six adult dogs (9.0\%) presented L. amazonensis antibodies, and this difference was not significant ( $\mathrm{p}$ $>0.05)$.

m e Assiations betwetnheropositivity and access to the streets were only analyzed in relation to the urban area. No such associations with $T$. gondii, N. caninum and $L$. amazonensis occurrence were observed.

All the dogs in the urban area that were sampled lived in dryland areas. However, 26 dogs in the rural area lived in dryland areas and 40 in seasonally flooded areas. Using only the samples from rural dogs, no association between the occurrence values, for each parasite, and living in dryland or seasonally flooded areas was observed $(p>0.05)$. These results are summarized in Table 2. 
Table 2 - Association between qualitative variables and dogs' seropositivity for $T$. gondii, N. caninum and $L$. amazonensis - Lábrea - 2013

\begin{tabular}{|c|c|c|c|c|c|c|}
\hline Variable & T. gondii & $\mathbf{P}$ & N. caninum & $\mathbf{P}$ & L. amazonensis & $\mathbf{P}$ \\
\hline $\begin{array}{l}\text { Sex } \\
\text { Female } \\
\text { Male }\end{array}$ & $\begin{array}{l}24 / 43(55.8) \\
37 / 56(66.1)\end{array}$ & 0.298 & $\begin{array}{c}0 / 43(0.0) \\
7 / 56(12.5)\end{array}$ & 0.018 & $\begin{array}{c}5 / 43(11.6) \\
3 / 56(5.3)\end{array}$ & 0.446 \\
\hline \multicolumn{7}{|l|}{ Age (years) } \\
\hline $0-1$ & $12 / 33(36.4)$ & 0.0006 & $2 / 33(6.1)$ & 0.887 & $2 / 33(6.1)$ & 0.887 \\
\hline \multicolumn{7}{|l|}{$\begin{array}{c}>1 \\
\text { Locality }\end{array}$} \\
\hline Urban area & $25 / 33(75.7)$ & 0.041 & $3 / 33(9.1)$ & 0.683 & $4 / 33$ & 0.671 \\
\hline Rural area & $36 / 66(54.5)$ & & $4 / 66(6.1)$ & & $4 / 66$ & \\
\hline $\begin{array}{c}\text { Living in dryland area } \\
\text { No } \\
\text { Yes }\end{array}$ & $\begin{array}{l}39 / 59(66.1) \\
22 / 40(55.0)\end{array}$ & 0.365 & $\begin{array}{l}4 / 59(6.8) \\
3 / 40(7.5)\end{array}$ & 0.791 & $\begin{array}{l}6 / 59(10.2) \\
2 / 40(5.0)\end{array}$ & 0.589 \\
\hline $\begin{array}{c}\text { Urban area } \\
\text { Access to streets } \\
\text { No }\end{array}$ & $\begin{array}{c}7 / 8(87.5) \\
18 / 25(72.0)\end{array}$ & 0.217 & $\begin{array}{l}1 / 8(62.5) \\
2 / 25(8.0)\end{array}$ & 1.000 & $\begin{array}{c}0 / 8(0.0) \\
4 / 25(16.0)\end{array}$ & 0.560 \\
\hline \multicolumn{7}{|l|}{$\begin{array}{c}\text { Yes } \\
\text { Rural area }\end{array}$} \\
\hline Dryland area & $14 / 26(53.8)$ & 0.862 & $1 / 26(3.8)$ & 0.655 & $2 / 26(7.7)$ & 0.920 \\
\hline Seasonally flooded area & $22 / 40(55.0)$ & & $4 / 40(7.5)$ & & $2 / 40(5.0)$ & \\
\hline
\end{tabular}

The T. gondii, N. caninum and L. amazonensis antibody titers are presented in Table 3. For T. gondii, approximately $50 \%$ of the positive animals presented high IgG antibody titers (1024 and 2048). Only one dog presented antibodies against all three of the parasites examined. Positivity for L. amazonensis and T. gondii was observed in six dogs and all dogs positive for $N$. caninum were also positive for $T$. gondii. An IgG antibody titer of 400 for N. caninum was the most common result.

\begin{tabular}{|c|c|c|c|c|c|}
\hline \multicolumn{2}{|c|}{ T. gondii } & \multicolumn{2}{|c|}{ N. caninum } & \multicolumn{2}{|c|}{ L. amazonensis } \\
\hline Titer & No. positive & Titer & No. positive & Titer & No. positive \\
\hline 64 & 4 & 100 & 2 & 40 & 1 \\
\hline 128 & 7 & 200 & 1 & 80 & 4 \\
\hline 256 & 5 & 400 & 3 & 160 & 2 \\
\hline 512 & 6 & 800 & 1 & 640 & 1 \\
\hline 1024 & 16 & & & & \\
\hline 2048 & 15 & & & & \\
\hline 4096 & 3 & & & & \\
\hline 8492 & 3 & & & & \\
\hline 32768 & 2 & & & & \\
\hline TOTAL & 61 & & 7 & & 8 \\
\hline
\end{tabular}

\section{Discussion}

All dogs presented during the visits to the riverine communities were sampled and the urban dogs were sampled in different sites of the municipality by a convenience sample. It was possible to collect samples once for each community or site visited; however, due to the very typical profile presented in the studied location and as no data is available in the region, the results, despite the relatively low number of dogs, are very important for the region.

The results indicate that dogs in this part of the Amazon region are exposed to $T$. gondii, N. caninum and L. amazonensis infection. 
None of the animals examined presented antibodies against $L$. infantum chagasi and $8.1 \%$ of the animals were positive to L. amazonensis.

The tripanosomatides, and not only the species of Leishmania, may have similar antigens (SUNDAR; RAI, 2002). The use of recombinant antigens is often not able to minimize cross-reactions because some proteins are very similar in the tripanosomatides and may cause cross-reactions (SUNDAR; RAI, 2002). Among the standard methodologies, only TESA blot proved extremely sensitive and specific, but this test is not commercially available (UMEZAWA et al., 2009). As cross-reactivity can occur, tests for two antigens were conducted; however, all animals were negative for $L$. infantum chagasi and some animals were positive for L. amazonensis. This fact demonstrates that, despite the expected cross-reactivity, probably these kinds of reactions were not observed in this study.

Occurrences of leishmaniasis have been correlated with deforestation processes, with subsequent colonization by competent vector species (DOURADO et al., 1989). The dogs sampled in this study lived in the municipality of Lábrea, which has a low degree of human disturbance. A study conducted in the same region recorded the existence of 32 species of sand flies, but none of these was identified as a vector of L. infantum chagasi (SILVA et al., 2014). However, the occurrence rate of cutaneous leishmaniasis in the Brazilian Amazon region is very high, especially in the state of Amazonas, and this favors infection among domestic animals (GUERRA et al., 2003).

Although cutaneous leishmaniasis is of wild origin, cases of this disease have been reported in urban environments within endemic areas. Dogs can be considered to be possible reservoirs of this disease, given that cutaneous leishmaniasis caused by $L$. amazonensis has been described in Brazil, among domestic dogs in São Paulo and Paraná (LAINSON, 2010; TOLEZANO et al., 2007; HOFFMANN et al., 2012).
The constant deforestation process that the Amazon region is suffering may favor the increased incidence of leishmaniasis in this region. Dogs have been neglected with regard to epidemiological studies on cutaneous leishmaniasis, but their presence seems to favor exchanges between vectors, wild animals, man and Leishmania species (LAINSON, 2010).

Seropositivity for $T$. gondii presented an association with the living area, such that dogs in the urban area of the municipality presented higher occurrences. The great majority of the dogs in urban areas in this part of the Amazon region have access to areas where cats are also present, like yards and streets. Thus, it is likely that this urban environment is more contaminated by $T$. gondii oocysts than rural environments. No association ( $p>0.05$ ) was observed between free access to the streets and positivity for $T$. gondii.

The system of flood and drought that is seen in the Purus River and in a large part of the rural area (várzeas and igapós) probably dilutes the environmental contamination by oocysts and, therefore, the animals' exposure. However, when the dogs in the rural area that were living in seasonally flooded and inundated areas were compared, it was not possible to find any association ( $\mathrm{p}>0.05)$, thus indicating that the real risk factor for $T$. gondii infection was probably the environment (rural versus urban).

The $T$. gondii occurrence rate found among the dogs sampled in the present study (61.6\%) was lower than the rates of $76.5 \%$ and $69.8 \%$ that were observed, respectively, among dogs in the urban area of Monte Negro, Rondônia (CAÑÓN-FRANCO et al., 2004) and in urban and rural areas of the state of Pará (VALADAS et al., 2010), which are both in the Amazon region. The increase in the occurrence rate with increasing age of the dogs observed in the present study was also found among the dogs in Monte Negro (CAÑON-FRANCO et al., 2004), thus indicating the existence of postnatal exposure to T. gondii. 
For $N$. caninum, the occurrence rate of $7.1 \%$ was also lower than the rates of $8.3 \%$ found in Rondônia (CAÑÓN-FRANCO et al., 2003) and 8.4\% found in the state of Pará (VALADAS et al., 2010). The seropositivity values obtained were similar in dogs of different ages and localities (urban and rural). The only variable associated with the presence of $N$. caninum antibodies was the sex of the dogs, such that all seven of the positive dogs were males. Very few studies conducted with dogs found association

\section{References}

ASHFORD, R. W. The leishmaniases as emerging and reemerging zoonoses. International Journal for Parasitology, v. 30, n. 12-13, p. 1269-1281, 2000. doi: 10.1016/S0020-7519(00)00136-3.

BRASIL. Ministério da Saúde. Secretaria de Vigilância em Saúde. Manual de vigilância da leishmaniose tegumentar americana. 2. ed. Brasília: 2010.

CAMARGO, M. E. Introdução às técnicas de imunofluorescência. Revista Brasileira de Patologia Clínica, v. 10, n. 2, p. 43-171, 1974.

CAÑÓN-FRANCO, W. A.; BERGAMASCHI, D. P.; LABRUNA, M. B.; CAMARGO L. M. A.; SILVA, J. C. R.; PINTER, A.; GENNARI, S. M. Occurrence of antiToxoplasma gondii antibodies in dogs in the urban area of Monte Negro, Rondônia, Brazil. Veterinary Research Communications, v. 28, n. 2, p. 113-118, 2004. doi: 10.1023/B:VERC.0000012114.71235.73.

CAÑÓN-FRANCO, W. A.; BERGAMASCHI, D. P.; LABRUNA, M. B.; CAMARGO L. M. A.; SOUZA, S. L. P.; SILVA, J. C. R.; PINTER, A.; DUBEY, J. P.; GENNARI, S. M. Prevalence of antibodies to Neospora caninum in dogs from Amazon, Brazil. Veterinary Parasitology, v. 115, n. 1, p. 7174, 2003. doi: 10.1016/S0304-4017(03)00131-6.

CRINGOLI, G.; RINALDI, L.; CAPUANO, F.; BALDI, L.; VENEZIANO, V.; CAPELLI, G. Serological survey of Neospora caninum and Leishmania infantum co-infection in dogs. Veterinary Parasitology, v. 106, n. 4, p. 307-313, 2002. doi: 10.1016/S0304-4017(02)00114-0.

DESJEUX, P. Leishmaniasis: current situation and new perspectives. Comparative Immunology, Microbiology between presence of $N$. caninum antibody and gender. G o ź d et ialk(2011), in Poland, observed higher seropositivity in female dogs; however, the gender seems to have little importance in the epidemiology of N. caninum infection in dogs (GENNARI, 2004).

\section{Acknowledgements}

The authors acknowledge the Health Department of the municipality of Lábrea and FAPESP for the financial support (2010/12371-5).

and Infectious Diseases, v. 27, n. 5, p. 305-318, 2004. doi: 10.1016/j.cimid.2004.03.004.

DOURADO, M. I. C.; NORONHA, C. V.; ALCANTARA, N.; ICHIHARA, M. Y. T.; LOUREIRO, S. Epidemiologia da leishmaniose tegumentar americana e suas relações com a lavoura e o garimpo, em localidade do Estado da Bahia. Brasil. Revista de Saúde Pública, v. 23, n. 1, p. 2-8, 1989. doi: 10.1590/S0034-89101989000100002.

DUBEY, J. P. Toxoplasmosis of animals and humans. $2^{\text {th }}$ ed. Boca Raton: CRC Press, 2010.

DUBEY, J. P.; HATTEL, A. L.; LINDSAY, D. S.; TOPPER, M. J. Neonatal Neospora caninum infection in dogs: Isolation of the causative agent and experimental transmission. Journal of the American Veterinary Medical Association, v. 193, n. 10, p. 1259-1263, 1988.

DUBEY, J. P.; JENKINS, M. C.; RAJENDRAN, C.; MISKA, K.; FERREIRA, L. R.; MARTINS, J.; KWOK, O. C. H.; CHOUDHARY, S. Gray Wolf (Canis Lupus) is a natural definitive host for Neospora caninum. Veterinary Parasitology, v. 181, n. 2-4, p. 382-387, 2011. doi: 10.1016/j.vetpar.2011.05.018.

DUBEY, J. P.; LAGO, E. G.; GENNARI, S. M.; SU, C.; JONES, J. L. Toxoplasmosis in humans and animals in Brazil: high prevalence, high burden of disease, and epidemiology. Parasitology, v. 139, n. 11, p. 1375-1424, 2012. doi: $10.1017 /$ S0031182012000765.

DUBEY, J. P.; SCHARES, G. Neosporosis in animals: the last five years. Veterinary Parasitology, v. 180, n. 1/2, p. 90-108, 2011. doi: 10.1016/j.vetpar.2011.05.031. 
FERRER, L.; AISA, M. J.; ROURA, X.; PORTÚS, M. Serological diagnosis and treatment of canine leishmaniasis. Veterinary Record, v. 136, n. 20, p. 514-516, 1995. doi: 10.1136/vr.136.20.514.

GENNARI, S. M. Neospora caninum no Brasil: situação atual da pesquisa. Revista Brasileira de Parasitologia Veterinária, v. 13, p. 23-28, 2004. Suplemento 1.

GENNARI, S. M.; CAÑÓN-FRANCO, W. A.; FEITOSA, M. M.; IKEDA, F. A.; LIMA, V. M. F.; AMAKU, M. Presence of anti-Neospora caninum and Toxoplasma gondii antibodies in dogs with visceral leishmaniosis from the region of Araçatuba, São Paulo, Brazil. Brazilian Journal of Veterinary Research and Animal Science, v. 43, n. 5, p. 613-619, 2006. doi: 10.11606/issn.1678-4456.bjvras.2006.26569.

GONDIM, L. F. P.; MCALLISTER, M. M.; PITT, W. C.; ZEMLICKA, D. E. Coyotes (Canis latrans) are definitive hosts of Neospora caninum. International Journal for Parasitology, v. 34, n. 2, p. 159-161, 2004. doi: 10.1016/j.ijpara.2004.01.001.

GOZDZIK, K.; WRZESIEN, R.; WIELGOSZ-OSTOLSKA, A.; BIEN, J.; KOZAK-LJUNGGREN, M.; CABAJ, W. Prevalence of antibodies against Neospora caninum in dogs from urban areas in Central Poland. Parasitology Research, v. 108, n. 4, p. 991-996, 2011. doi: 10.1007/s00436-010-2143-0.

GRAMICCIA, M.; GRADONI, L. The current status of zoonotic leishmaniasis and approaches to disease control. International Journal for Parasitology, v. 35, n. 11-12, p. 1169-1180, 2005. doi: 10.1016/j.ijpara.2005.07.001.

GUERRA, J. A. O.; TALHARI, S.; PAES, M. G.; GARRIDO, M.; TALHARI, J. M. Aspectos clínicos e diagnósticos da leishmaniose tegumentar americana em militares simultaneamente expostos à infecção na Amazônia. Revista da Sociedade Brasileira de Medicina Tropical, v. 36, n. 5, p. 587-590, 2003. doi: 10.1590/S0037-86822003000500008.

HOFFMANN, A. R.; NAVARRO, I. T.; CAMARGOJUNIOR, V. E.; CALDART, E. T.; BREGANÓ, R. M.; PEREIRA, P. M. Leishmania amazonensis em cão com quadro clínico de leishmaniose visceral no Estado do Paraná, Brasil- relato de caso. Semina: Ciências Agrárias, v. 33, n. 6, p. 3265-3270, 2012. Suplemento 2. doi: 10.5433/1679-0359.2012v33n6Supl2p3265.

KING, J. S.; SLAPETA, J.; JENKINS, D. J.; AL-QASSAB, S. E.; ELLIS, J. T.; WINDSOR, P. A. Australian dingoes are definitive hosts of Neospora caninum. International
Journal for Parasitology, v. 40, n. 8, p. 945-950, 2010. doi: 10.1016/j.ijpara.2010.01.008.

LAINSON, R. Espécies neotropicais de Leishmania: uma breve revisão histórica sobre sua descoberta, ecologia e taxonomia. Revista Pan-Amazônica de Saúde, v. 1, n. 2, p. 13-32, 2010. doi: 10.5123/S2176-62232010000200002.

MCALLISTER, M. M.; DUBEY, J. P.; LINDSAY, D. S.; JOLLEY, W. R.; WILLS, R. A.; MCGUIRE, A. M. Dogs are definitive hosts of Neospora caninum. International Journal for Parasitology, v. 28, n. 9, p. 1473-1478, 1998. doi: 10.1016/S0020-7519(98)00138-6.

PARÉ, J.; FECTEAU, G.; FORTIN, M.; MARSOLAIS, G. Seroepidemiologic study of Neospora caninum in dairy herds. Journal of the American Veterinary Medical Association, v. 213, n. 11, p. 1595-1598, 1998.

SAWADA, M.; PARK, C. H.; KONDO, H.; MORITA, T.; SHIMADA, A.; YAMANE, I.; UMEMURA, T. Serological survey of antibody to Neospora caninum in Japanese dogs. Journal of Veterinary Medical Science, v. 60, n. 7, p. 853854, 1998. doi: 10.1292/jvms.60.853.

SILVA, A. E. P.; ANGELIS, C. F.; MACHADO, L. A. T.; WAICHAMAN, A. V. Influência da precipitação na qualidade da água do Rio Purus. Acta Amazonica, v. 38, n. 4, p. 733742, 2008. doi: 10.1590/S0044-59672008000400017.

SILVA, T. R. R.; ASSIS, M. D. G.; FREIRE, M. P.; REGO, F. D.; GONTIJO, C. M. F.; SHIMABUKURO, P. H. F. Molecular detection of Leishmania in Sand Flies (Diptera: Psychodidae: Phlebotominae) collected in the Caititu Indigenous Reserve of the Municipality of Lábrea, State of Amazonas, Brazil. Journal of Medical Entomology, v. 51, n. 6, p. 1276-1282, 2014. doi: 10.1603/ME14025.

SILVA, D. A. O.; CABRAL, D. D.; BERNARDINA, B. L. D.; SOUZA, M. A.; MINEO, J. R. Detection of Toxoplasma gondii-specific antibodies in dogs: a comparative study of immunoenzymatic, immunofluorescent and haemagglutination titers. Memórias do Instituto Oswaldo Cruz, v. 92, n. 6, p. 785-789, 1997 . doi: 10.1590/S007402761997000600010 .

SOARES, H. S.; CAMARGO, L. M.; GENNARI, S. M.; LABRUNA, M. B. Survey of canine tick-borne diseases in Lábrea, Brazilian Amazon: 'accidental' findings of Dirofilaria immitis infection. Brazilian Journal of Veterinary Parasitology, v. 23, n. 4, p. 473-480, 2014. doi: 10.1590/S1984-29612014093. 
SOUZA, S. L. P.; GENNARI S. M.; YAI, L. E. O.; D'AURIA, S. R. N.; CARDOSO, S. M. S.; GUIMARÃES JÚNIOR, J. S.; DUBEY, J. P. Occurrence of Toxoplasma gondii antibodies in sera from dogs of the urban and rural areas from Brazil. Revista Brasileira de Parasitologia Veterinária, v. 12, n. 1, p. 1-3, 2003.

SUNDAR, S.; RAI, M. Laboratory diagnosis of visceral leishmaniasis. Clinical and Diagnostic Laboratory Immunology, v. 9, n. 5, p. 951-958, 2002. doi: 10.1128/CDLI.9.5.951-958.2002.

TOLEZANO, J. E.; ULIANA, S. R.; TANIGUCHI, H. H.; ARAÚJO, M. F.; BARBOSA, J. A.; BARBOSA, J. E.; FLOETER-WINTER, L. M.; SHAW, J. J. The first records of Leishmania (Leishmania) amazonensis in dogs (Canis familiaris) diagnosed clinically as having canine visceral leishmaniasis from Araçatuba County, São Paulo State, Brazil. Veterinary Parasitology, v. 149, n. 3-4, p. 280-284, 2007. doi: 10.1016/j.vetpar.2007.07.008.
UMEZAWA, E. S.; SOUZA, A. I.; PINEDO-CANCINO, V.; MARCONDES, M.; MARCILI, A.; CAMARGO, L. M.; CAMACHO, A. A.; STOLF, A. M.; TEIXEIRA, M. M. TESA-blot for the diagnosis of Chagas disease in dogs from co-endemic regions for Trypanosoma cruzi, Trypanosoma evansi and Leishmania chagasi. Acta Tropica, v. 111, n. 1, p. 15-20, 2009. doi: 10.1016/j.actatropica.2009.01.006.

VALADAS, S.; MINERVINO, A. H. H.; LIMA, V. M. F.; SOARES, R. M.; ORTOLANI, E. L.; GENNARI, S. M. Occurrence of antibodies anti-Neospora caninum, antiToxoplasma gondii, and anti-Leishmania chagasi in serum of dogs from Pará State, Amazon, Brazil. Parasitology Research, v. 107, n. 2, p. 453-457, 2010. doi: 10.1007/s00436-010-1890-2.

WOUDA, W.; DUKSTRA, T.; KRAMER, A. M. H.; VAN MAANEN, C.; BRINKHOF, J. M. A. Seroepidemiological evidence for a relationship between Neospora caninum infections in dogs and cattle. International Journal for Parasitology, v. 29, n. 10, p. 1677-1682, 1999. doi: 10.1016/S0020-7519(99)00105-8. 